\title{
DIVING BEHAVIOR AND FORAGING AREAS OF THE NEOTROPIC CORMORANT AT A MARINE COLONY IN PATAGONIA, ARGENTINA
}

\author{
FLAVIO QUINTANA, ${ }^{1,5}$ PABLO YORIO,${ }^{1}$ NORA LISNIZER,${ }^{2}$ \\ ALEJANDRO GATTO,${ }^{3}$ AND GASPAR SORIA ${ }^{4}$
}

\begin{abstract}
The Neotropic Cormorant (Phalacrocorax brasilianus) is a widespread and abundant species distributed throughout the Neotropics. We report on diving behavior and foraging areas of Neotropic Cormorants in inshore marine waters of Patagonia, Argentina. Mean dive duration was $18.9 \pm 5.3$ sec and differed significantly among birds. Maximum dive duration was $43 \mathrm{sec}$. Birds spent 58-79\% of their time at sea underwater. Mean recovery time at the surface between successive dives was $6.7 \pm 1.5 \mathrm{sec}$, and was also significantly different among individuals. Mean diving efficiency (mean dive duration time/mean recovery time) was $2.6 \pm$ 0.5 (range: $0.5-4.6$ ). We were able to locate birds while feeding on 112 of 215 occasions. Almost $90 \%$ of mapped locations (68 feeding trips) were within $2.5 \mathrm{~km}$ of the colony. However, we did not receive a signal on 103 occasions, suggesting that foraging may also occur in waters outside the inlet where the colony was located. High variability in dive duration and recovery time is congruent with flexible foraging techniques and diet, as Neotropic Cormorants feed on both bottom and pelagic schooling fish. Received 8 July 2003, accepted 26 March 2004.
\end{abstract}

The Neotropic Cormorant (Phalacrocorax brasilianus), is widely distributed in the Neotropics. The species ranges from the southern United States to Cape Horn at the southern extreme of South America (Orta 1992, Telfair and Morrison 1995). Neotropic Cormorants are one of the few cormorant species that occupy both freshwater and marine environments, breeding in inland wetlands, fast-flowing rivers, high-altitude lakes, and on marine shores and islands (Orta 1992). Like other cormorants and shags (see Johnsgard 1993 for a review), they are foot-propelled pursuit-divers, although they can feed by plunge-diving under special sea conditions (Duffy et al. 1986, Humphrey and Rasmussen 1988).

In Argentina, the Neotropic Cormorant is a widespread and abundant species, with colonies reaching up to several thousand individuals at some wetlands in northern and central

\footnotetext{
${ }^{1}$ Centro Nacional Patagónico (CONICET) and Wildlife Conservation Society, Blvd. Brown 3500, (9120) Puerto Madryn, Chubut, Argentina.

${ }^{2}$ Facultad de Ciencias Naturales y Museo, Univ. Nacional de La Plata (1900), La Plata, Buenos Aires, Argentina.

${ }^{3}$ Facultad de Ciencias Exactas y Naturales, Univ. de Buenos Aires (C1428EHA), Buenos Aires, Argentina.

${ }^{4}$ Univ. Nacional de la Patagonia, Blvd. Brown 3700, (9120) Puerto Madryn, Chubut, Argentina.

${ }^{5}$ Corresponding author; e-mail: quintana@cenpat.edu.ar
}

Argentina (De la Peña 1980, Navas 1993). On the marine coasts of Patagonia, it breeds at twelve sites with a total breeding population estimated at 1,200 pairs (Yorio et al. 1999). Despite its abundance and broad distribution, the Neotropic Cormorant has been little studied throughout its range (Telfair and Morrison 1995). In Argentina, general aspects of its breeding biology and behavior have been described for freshwater populations (Bo 1956, Daneri 1960, Aramburu and Bo 1961, De la Peña 1980, Mosqueira et al. 1987) but relatively little has been published on marine populations (Yorio et al. 1994, Quintana et al. 2002b). To date, there is little information on the feeding ecology of the Neotropic Cormorant, and no available data on diving parameters of birds feeding in freshwater or marine environments. Here, we report on the diving behavior and use of foraging areas of this species in inshore marine waters of Patagonia, Argentina.

\section{METHODS}

During the 2001 breeding season, we studied the diving behavior and determined the feeding areas of the Neotropic Cormorant at a colony of 120 breeding pairs at Isla Vernaci Sudoeste, Caleta Malaspina $\left(45^{\circ} 11^{\prime} \mathrm{S}, 66^{\circ} 30^{\prime}\right.$ W), Chubut, Argentina (Fig. 1). This island complex is located at the mouth of an inlet (35 km²; Herrera 1997) where 9 of 16 seabird 


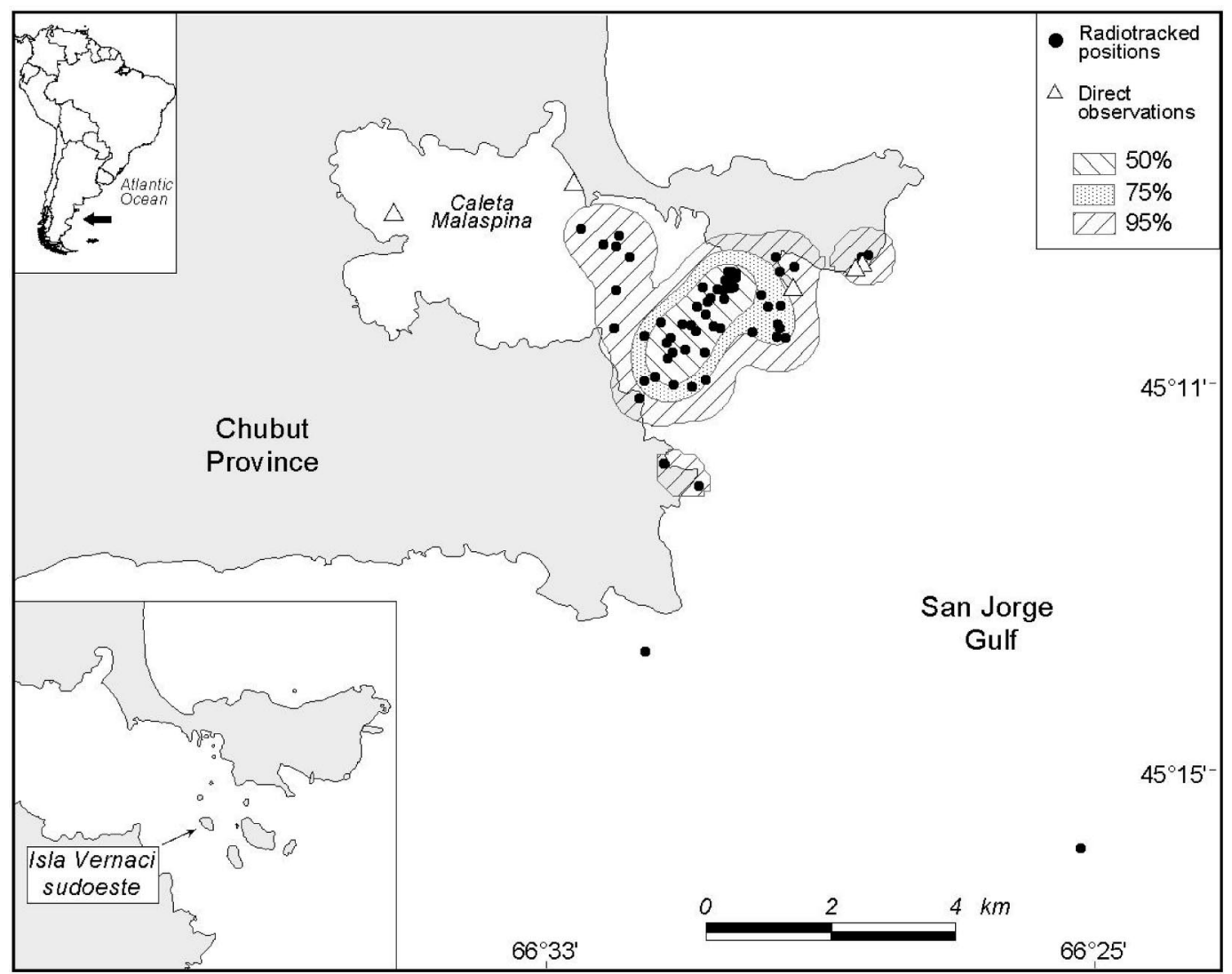

FIG. 1. Foraging locations and density contours (resulting from kernel estimation of locations) for Neotropic Cormorants breeding at Isla Vernaci Sudoeste (Caleta Malaspina, Argentina), 2001. Contours encompass 50, 75, and $95 \%$ of locations.

species that breed along the Argentine Patagonian coast have colonies (Yorio et al. 1998).

A VHF radio transmitter (Standard model, Advanced Telemetry Systems, Bethel, MN) was attached to eight adult birds during the late incubation period (29 November). Radios were fixed to the two central tail feathers using waterproof tape (Wanless et al. 1998). The procedure was completed in less than $5 \mathrm{~min}$ and the released birds flew directly to sea before returning to their nests. Mean weight of radios was $18.4 \mathrm{~g}(\mathrm{SD}=0.2, n=6)$, approximately $1 \%$ of adult body mass (mean $=1.65$ $\mathrm{kg}, \mathrm{SD}=0.2, n=8$ birds). Transmitters did not appear to affect cormorant breeding and feeding activities.

Radio signals were monitored from 11 tracking stations separated by $0.7-9.3 \mathrm{~km}$, located on shore at $10-50 \mathrm{~m}$ above sea-level.
Receivers were single channel (R161A model, Advanced Telemetry Systems, MN) connected to hand held 3-element Yagi aerials (Advanced Telemetry Systems). Radio signals disappeared when birds were underwater and resumed when cormorants resurfaced. It was therefore possible to identify a sequence of dives as a series of regular breaks in the signal (see Wanless et al. 1991). Dive duration corresponded to the time interval over which the signal was interrupted and recovery times (the interval at the surface between successive dives) to the time during which a signal was audible. Dive efficiency was defined as the ratio between mean dive duration and mean recovery time (Dewar 1924). Birds were radiotracked throughout daylight hours between 29 November and 3 December 2001.

Birds were treated individually because dif- 
TABLE 1. Dive parameters of Neotropic Cormorants at Caleta Malaspina, Argentina, during the 2001 breeding season.

\begin{tabular}{lcccccc}
\hline Bird & $\begin{array}{c}\text { Number of } \\
\text { dives }\end{array}$ & $\begin{array}{c}\text { Trips } \\
\text { recorded }\end{array}$ & $\begin{array}{c}\text { Mean dive } \\
\text { duration }(\mathrm{sec}) \\
\pm \mathrm{SD}\end{array}$ & $\begin{array}{c}\text { Maximum dive } \\
\text { duration (sec) }\end{array}$ & $\begin{array}{c}\text { Mean recovery } \\
\text { time } \\
\pm \text { SD }\end{array}$ & $\begin{array}{c}\% \text { time } \\
\text { underwater } \pm \text { SD }\end{array}$ \\
\hline 14 & 213 & 4 & $15.2 \pm 6.9$ & 33 & $5.0 \pm 2.3$ & $69.2 \pm 9.2$ \\
54 & 113 & 2 & $16.9 \pm 4.1$ & 28 & $6.2 \pm 2.2$ & $72.6 \pm 3.6$ \\
104 & 6 & 1 & $22.8 \pm 7.0$ & 30 & $9.8 \pm 1.2$ & 69.9 \\
133 & 251 & 5 & $15.9 \pm 8.5$ & 35 & $6.5 \pm 4.0$ & $58.4 \pm 17.7$ \\
143 & 95 & 2 & $13.4 \pm 8.2$ & 30 & $5.5 \pm 3.5$ & $70.2 \pm 3.7$ \\
153 & 176 & 5 & $28.6 \pm 8.9$ & 43 & $7.1 \pm 2.4$ & $79.4 \pm 4.4$ \\
163 & 65 & 1 & $19.3 \pm 6.1$ & 32 & $6.8 \pm 2.5$ & 71.5 \\
Total & 919 & 20 & & & & \\
Mean \pm SD & & & $18.9 \pm 5.3$ & & $6.7 \pm 1.5$ & $70.2 \pm 6.2$ \\
\hline
\end{tabular}

a Excludes recovery times $>20 \mathrm{sec}$.

ferences between birds were significant (oneway ANOVA, $P<0.05$ ). Means of diving parameters were determined for each individual and then pooled to calculate overall mean values. The use of non-independent observations is valid if the replicates are pooled to estimate a mean value (Hurlbert 1984).

Feeding areas were defined as the locations where birds dived repeatedly; these were estimated by triangulation from the direction of the radio signals. During feeding trips, and while birds were at the surface between consecutive dives, at least two stations simultaneously recorded the direction of the most stable and strongest signal. Observers at the two tracking stations were in radio contact. To control for errors, an observer with binoculars and a hand-held aerial checked a sample of positions. We used kernel density estimates to

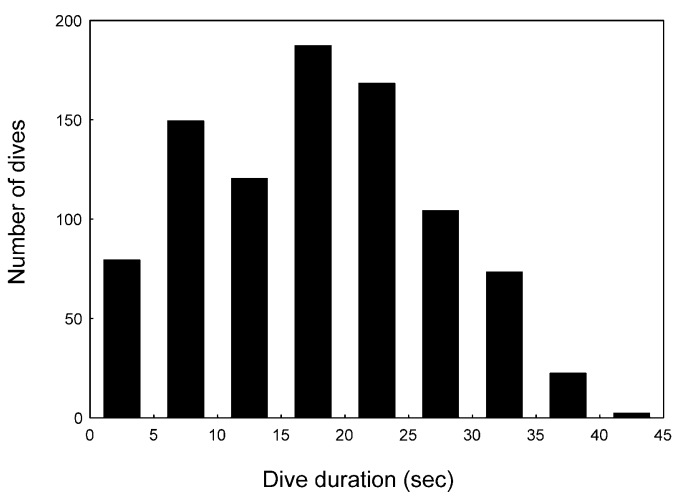

FIG. 2. Frequency distribution of dive durations ( $n$ $=919$ dives) for Neotropic Cormorants at Caleta Malaspina, Argentina, 2001, during the late incubation period. characterize the spatial distribution of feeding locations following Wood et al. (2000). We defined three categories of activity ranges as the areas encompassing 95, 75, and $50 \%$ of locations at sea.

\section{RESULTS}

Diving behavior.-We recorded 919 dives from seven incubating birds during 20 feeding trips (Table 1). We were unable to obtain data from one of the eight instrumented birds due to radio failure. Mean dive duration was 18.9 $\sec (\mathrm{SD}=5.3, n=7$ birds; Table 1$)$ and modal dive duration was $15-20 \mathrm{sec}$. Only $3 \%$ of the dives $(n=919)$ were longer than $35 \mathrm{sec}$ (Fig. 2). Maximum dive duration was $43 \mathrm{sec}$ and birds spent between 58 and $79 \%$ of their time at sea underwater (Table 1). Dive duration differed among individuals (Kruskal-Wallis $H=252.5, n=887, P<0.001)$. Recovery time, excluding prolonged surface intervals (PSI) longer than $20 \mathrm{sec}$, was $6.7 \mathrm{sec}(\mathrm{SD}=$ $1.5, n=7$ birds; Table 1). PSIs ranged from 21 to $199 \mathrm{sec}$ and were infrequent (3\% of total surface intervals). Recovery time differed among individuals (Kruskal-Wallis $H=72.3$, $n=871, P<0.001)$. Mean diving efficiency was $2.6 \pm 0.5$ ( $n=6$ birds). The correlation between dive duration and subsequent recovery time was low $\left(r^{2}=0.0003, n=892, P\right.$ $>0.05)$. Recovery time increased linearly with duration of the previous dive (Recovery time $=7.0+0.02 \times$ Dive duration) but the slope was low and non-significant $\left(t_{890}=0.5\right.$, $P>0.05)$.

Both dive duration and recovery time differed among trips for three birds, while only 
one (either dive duration or recovery time) differed for two other birds (Kruskal-Wallis and Mann-Whitney $U$-tests, $H>14$ and $Z>$ $3.5, n=94-236$ dives per bird, all $P<0.05$ ). We excluded two birds (nos. 104 and 163) from the analysis, as only one trip was recorded for each of these birds.

In a diving sequence, the birds performed a general pattern of immersions longer than the intervals on the surface, except for one trip of bird no. 133. Time underwater during foraging trips varied from 31 to $84 \%$ of the time at sea, but in $60 \%$ of the trips $(n=20)$ the birds foraged underwater more than $70 \%$ of the time. Within a feeding trip, dive duration and recovery time were variable, with $\mathrm{CV}$ ranging from 13 to $54 \%$ and 20 to $252 \%$ for dive duration and recovery time, respectively.

Foraging areas.-Both telemetry and observational data indicated that Neotropic Cormorants from Isla Vernaci Sudoeste fed in inshore and shallow waters $(<1.3 \mathrm{~km}$ from the coast and $<10 \mathrm{~m}$ depth) both inside and outside the inlet. We were able to locate birds while feeding inside the inlet on 112 occasions $(52 \%, n=215)$. However, we did not receive a signal on 103 occasions $(48 \%, n=$ 215) while the birds were absent from the colony. Both tagged and untagged individuals were observed outside the inlet diving in inshore waters in small bays located at both sides of its mouth.

Inside the inlet, 71 feeding areas were identified by means of radio telemetry for 68 foraging trips (three foraging trips included two locations; Fig. 1). We also observed four of the eight instrumented birds feeding inside the inlet on a total of six occasions (Fig. 1). Eighty seven percent of mapped locations ( $n$ $=71$ ) were within $2.5 \mathrm{~km}$ of the colony, near the mouth of the inlet (Fig. 1). During a single trip, cormorants almost invariably used the same foraging area; on only 2 of the 68 trips did the birds change foraging sites.

\section{DISCUSSION}

Diving behavior.-Our study presents the first description of the diving behavior of the Neotropic Cormorant in marine waters. Our results show that Neotropic Cormorants dive near the coast in shallow waters. The diving pattern consisted of extremely short dives not exceeding $20 \mathrm{sec}$ in $97 \%$ of the recorded dives, followed by short intervals at the surface. Morrison et al. (1978) reported a similar diving pattern for adult Neotropic Cormorants foraging in a freshwater pond in Texas, USA. Diving durations and recovery times of the Neotropic Cormorant were markedly shorter than those of Rock Shags (Phalacrocorax magellanicus) and Imperial Cormorants (Phalacrocorax atriceps) breeding in the same study area. Neotropic Cormorants performed shorter dives (18.9 sec compared to 47.2 and $94.8 \mathrm{sec}$ for Rock Shags and Imperial Cormorants, respectively) and spent shorter intervals at the surface (6.7 sec compared to 15.5 and 163.6 sec for the Rock Shag and Imperial Cormorant, respectively) (Quintana 1999, Quintana et al. 2002a, Sapoznikow and Quintana 2003; FQ unpubl. data).

While Rock Shags and Imperial Cormorants show a diving pattern that is characteristic of bottom feeders (Quintana 1999, Quintana et al. 2002a, Sapoznikow and Quintana 2003; FQ unpubl. data), the Neotropic Cormorant shows a more flexible diving strategy. Wilson and Wilson (1988) suggested that besides physiological constraints related to body mass, differences in diving behavior could reflect variation in features of foraging areas such as bathymetry, bottom topography, water turbidity, and type and/or availability of prey. Because our data from Rock Shags and Imperial Cormorants also come from adult birds feeding within Caleta Malaspina during the same part of the season, differences in environmental characteristics of foraging areas do not seem to be a plausible explanation for differences in diving behavior. Rather, differences in diving depths, foraging techniques, and diet may best explain dissimilar diving patterns found among these three sympatric species.

In our study area, Neotropic Cormorants have been observed foraging individually as well as in flocks (FQ pers. obs.); Imperial Cormorants seldom engage in group foraging and Rock Shags always forage alone (Quintana et al. 2002a, Punta et al. 2003). In addition, even when pursuit diving appears to be the usual feeding behavior, Neotropic Cormorants have been observed foraging in flocks by plungediving in very shallow and coastal waters (Duffy et al. 1986, Humphrey and Rasmussen 1988; FQ pers. obs). Similar foraging tech- 
niques for Neotropic Cormorants also have been observed in Puerto Deseado, Santa Cruz, Argentina (P. A. Gandini and E. Frere pers. comm.). In accordance with the more flexible foraging strategy shown by Neotropic Cormorants in our study area, preliminary data suggest that their diet includes a higher proportion of surface-schooling fish than that of the other two cormorant species (Malacalza et al. 1994, 1997; Gosztonyi and Kuba 1998; Punta et al. 2003; FQ and PY unpubl. data). The high within-trip variability in dive duration and recovery time found in Neotropic Cormorants in this study is congruent with their flexible foraging techniques and diet. In Caleta Malaspina, Neotropic Cormorants appear to spend time searching for sheltered, but predictable, bottom-dwelling prey as well as pelagic schooling fish when they occur in the area. This probably results in the variability in their diving parameters. A theoretical model developed by Grémillet and Wilson (1999) for the Great Cormorant (Phalacrocorax carbo) predicts that cormorant diving parameters are most strongly influenced by prey availability.

Foraging areas.-Neotropic Cormorants often foraged within Caleta Malaspina in an area close to the colony at the mouth of the inlet. We did not detect radio signals almost half of the time birds were absent from the colony, suggesting that the cormorants also regularly forage outside the inlet. In some of these cases, however, birds may have been feeding in areas behind islands or in small bays hidden behind elevated terrain, which interfered with signal transmission. This was confirmed in several cases through direct observation of tagged individuals and simultaneous radio-tracking. Observations along the outer coasts of the inlet revealed that birds forage in inshore waters of small bays.

Foraging activity was concentrated in specific coastal sections of Caleta Malaspina, mostly at the mouth of the inlet; we rarely observed foraging at the inland end of the inlet. Birds there generally foraged in mixed feeding flocks, likely taking advantage of pelagic prey which had moved into that part of the inlet. Neotropic Cormorants also regularly occur in association with the commercial harvesting activities of macroalgae, as the harvesting sledge stirs the ocean bottom and likely makes bottom fishes more accessible to the birds (H. Hernández pers. comm.). This and other activities, such as mariculture and occasional guano harvesting from Imperial Cormorant colonies, also likely affect the foraging behavior and spatial distribution of Neotropic Cormorants. Our study on foraging patterns and locations should help in the definition of spatial and temporal harvest zoning schemes and help prevent modification of key feeding habitats.

\section{ACKNOWLEDGMENTS}

Research was funded by grants from the Wildlife Conservation Society, Consejo Nacional de Investigaciones Científicas y Técnicas, and Agencia de Promoción Científica y Tecnológica. We thank R. Vera and M. A. Díaz for field assistance and P. Dell'Arciprete for spatial analysis of data. We thank R. C. Telfair, II, and two anonymous reviewers for comments that improved the manuscript. We also thank Centro Nacional Patagónico (CONICET) for institutional support and Soriano S.A. for logistical support.

\section{LITERATURE CITED}

Aramburu, R. H. And N. A. Bo. 1961. Descripción de colonias de nidificación (Delta del Paraná y Golfo San José, Chubut) y estudio de los estados juveniles de Phalacrocorax brasilianus (Gmelin). Revista del Museo de Ciencias Naturales de La Plata 7:107-121.

Bo, N. A. 1956. Observaciones ecológicas y etológicas sobre el Biguá. Hornero 10:147-157.

DANERI, C. A. 1960. La nidificación del Biguá Phalacrocorax olivaceus olivaceus (H.) en Puerto Deseado. Physis 21:273-277.

DE LA PEÑA, M. R. 1980. Notas nidológicas sobre biguaes y cormoranes (Aves: Anhingidae y Phalacrocoracidae). Historia Natural 1:109-112.

DEWAR, J. M. 1924. The bird as a diver: a contribution to the natural history of diving birds. H. F. \& G. Witherby, London, United Kingdom.

Duffy, D. C., R. P. Wilson, M. P. Wilson, AND C. Velasquez R. 1986. Plunge-diving by Olivaceous Cormorants in Chile. Wilson Bulletin 98:607-608.

Gosztonyi, A. E. And L. KubA. 1998. Fishes in the diet of the Imperial Cormorant Phalacrocorax atriceps at Punta Lobería, Chubut, Argentina. Marine Ornithology 26:59-61.

Grémillet, D. And R. P. Wilson. 1999. A life in the fast lane: energetics and foraging strategies of the Great Cormorant. Behavioral Ecology 10:516524.

HerRERA, G. O. 1997. Dieta reproductiva de la gaviota de Olrog Larus atlanticus en la provincia del Chubut. Undergraduate thesis, Universidad Nacional de la Patagonia San Juan Bosco, Puerto Madryn, Argentina.

Humphrey, P. S., P. C. Rasmussen, AND N. Lopez. 1988. Fish surface activity and pursuit-plunging 
by Olivaceous Cormorants. Wilson Bulletin 100: 27-328.

Hurlbert, S. H. 1984. Pseudoreplication and the design of ecological field experiments. Ecological Monographs 54:187-211.

JohnsGaRD, P. A. 1993. Cormorants, darters, and pelicans of the world. Smithsonian Institution Press, Washington, D.C.

Malacalza, V. E., N. M. Bertellotti, and T. I. PoRETTI. 1997. Variación estacional de la dieta de Phalacrocorax magellanicus (Aves: Phalacrocoracidae) en Punta Loma (Chubut, Argentina). Neotrópica 43:35-37.

Malacalza, V. E., T. I. Poretti, And N. M. BertelLOTTI. 1994. La dieta de Phalacrocorax albiventer en Punta León (Chubut, Argentina) durante la temporada reproductiva. Ornitología Neotropical 5:91-97.

Morrison, M. L., R. D. Slack, And E. Shanley, JR. 1978. Age and foraging ability relationships of Olivaceous Cormorants. Wilson Bulletin 90:414422.

Mosqueira, M. E., M. V. Albeza, And G. M. De GonZO. 1987. Biología reproductiva de Phalacrocorax olivaceus (Humboldt, 1905) en el valle de Lerma, Salta. Revista de la Asociación de Ciencias Naturales del Litoral 18:163-173.

Navas, J. R. 1993. Aves: Podicipediformes y Pelecaniformes. Fauna de agua dulce de la República Argentina, vol. $43\left(1^{\mathrm{a}}\right)$. Profadu (CONICET), Museo de la Plata, La Plata, Argentina.

ORTA, J. 1992. Family Phalacrocoracidae (cormorants). Pages 326-353 in Handbook of the birds of the world, vol. 1: ostrich to ducks (J. del Hoyo, A. Elliott, and J. Sargatal, Eds.). Lynx Edicions, Barcelona, Spain.

Punta, G., P. Yorio, And G. Herrera. 2003. Temporal patterns in the diet and food partitioning in Imperial Cormorants (Phalacrocorax atriceps) and Rock Shags (P. magellanicus) breeding at Bahía Bustamante, Argentina. Wilson Bulletin 115:307315.

QuintanA, F. 1999. Diving behavior of Rock Shags at a Patagonian Colony of Argentina. Waterbirds 22: 466-471.

Quintana, F., F. Morelli, and Y. Benedetti. 2002a. Buceo eficiente en aguas poco profundas: comportamiento de buceo y patrón de alimentación del
Cormorán Cuello Negro, Phalacrocorax magellanicus, en dos colonias de la costa Patagónica. Ecología Austral 12:19-28.

Quintana, F., P. Yorio, And P. García Borboroglu. 2002b. Aspects of the breeding biology of the Neotropic Cormorant Phalacrocorax olivaceus at Golfo San Jorge, Patagonia, Argentina. Marine Ornithology 30:25-29.

SAPOZnikow, A. And F. Quintana. 2003. Foraging behavior and feeding locations of Imperial Cormorants and Rock Shags breeding sympatrically in Patagonia, Argentina. Waterbirds 26:184-191.

Telfair, R. C., II, AND M. L. Morrison. 1995. Neotropic Cormorant (Phalacrocorax brasilianus). The Birds of North America, no. 137.

WANLess, S., D. Grémillet, AND M. P. Harris. 1998. Foraging activity and performance of Shags Phalacrocorax aristotelis in relation to environmental characteristics. Journal of Avian Biology 29:4954.

Wanless, S., M. P. Harris, And J. A. Morris. 1991. Foraging range and feeding locations of Shags Phalacrocorax aristotelis during chick rearing. Ibis 133:30-36.

Wilson, R. P. AND M. P. T. WiLson. 1988. Foraging behavior in four sympatric cormorants. Journal of Animal Ecology 57:943-955.

Wood, A. G., B. Naef-Daenzer, P. A. Prince, and J. P. Croxall. 2000. Quantifying habitat use in satellite-tracked pelagic seabirds: application of kernel estimation to albatross locations. Journal of Avian Biology 31:278-286.

Yorio, P., E. Frere, P. Gandini, and W. Conway. 1999. Status and conservation of seabirds breeding in Argentina. Bird Conservation International 9:299-314.

Yorio, P., E. Frere, P. Gandini, ANd G. Harris (Eds.). 1998. Atlas de la distribución reproductiva de aves marinas en el litoral Patagónico Argentino. Plan de manejo integrado de la zona costera Patagónica. Fundación Patagonia Natural and Wildlife Conservation Society. Instituto Salesiano de Artes Gráficas, Buenos Aires, Argentina.

Yorio, P., F. Quintana, C. CAMPagna, ANd G. Harris. 1994. Diversidad, abundancia y dinámica espaciotemporal de la colonia mixta de aves marinas en Punta León, Patagonia. Ornitología Neotropical 5: 69-77. 